\title{
An unexpected behavior of a patient after a diastema closure treatment *
}

\author{
Mağrur Kazak $^{\alpha}$, Sevda Öztürk ${ }^{\beta}$ \\ Selcuk Dent J, 2017; 4: 89-93 (Doi: 10.15311/1441.330627)
}

Bașuru Tarihi: 01 Subat 2017 Yayına Kabul Tarihi: 29 Nisan 2017

\begin{abstract}
An unexpected behavior of a patient after a diastema closure treatment

In today's dentistry, it is easy to find a solution and to create an aesthetic restoration with the help of new restorative materials and techniques. Maxillary midline diastema is regarded as a cause of non-aesthetic appearance for some patients. Midline diastema can occur due to a variety of reasons such as labial frenulum to congenital causes. One of the treatment techniques of the midline diastema is to restore it with composite material. Composite diastema closure prepared by silicon index on a wax up model is practical, easy, predictable, low-cost, and minimal invasive technique. In this case, after a diastema closure treatment, the removal of the restorations in two days due to the patient's indecision is reported. 24 years old female patient applied to the clinic with the compliant of a wide diastema between the maxillary central incisors. The treatment procedure was explained and the patient signed the consent form. Firstly, a diagnostic waxup model was prepared showing the final restorations on the model which was approved by the patient. Diastema closure was restored with a nano-hybrid composite material. As a result, before deciding an invasive treatment procedure in an indecisive patient, it would be more appropriate to prefer composite laminate veneers as the primary treatment option regarding the patients adaptation period to the new restorations.
\end{abstract}

\section{KEYWORDS}

Aesthetics, conservative therapy, diastema, perception

Basically maxillary anterior spacing or diastema can be defined as the space between two frontal teeth. It is a common formation which is frequently observed in children especially in the mixed dentition stage. ${ }^{1}$ Along with the natural occurrence of diastema; some traumatic incidents, habits such as thumb sucking or excessive usage of feeder and teat in early infancy can lead the diastema to happen as well as openbite. As it is understood from the causes of

\begin{abstract}
Öz
Bir diastema kapatma işlemi sonrasında hastanın beklenmeyen davranışı

Estetik görünümden uzak dişlerin çözümünü bulmak ve estetik restorasyonlar yapmak yeni materyaller ve teknikler sayesinde artık çok kolaylaşmıştır. Hastaların en büyük estetik şikayetlerinden biri maksilla orta hat diasteması'dır. Labial frenulumdan konjenital sebeplere kadar pek çok farklı nedenlerden dolayı orta hat diasteması oluşabilir. Orta hat diastema tedavi tekniklerinden biri dişlerin kompozit materyali ile restore edilmesidir. Wax-up model üzerinde silikon anahtar hazırlanarak kompozit materyalle yapılmış diastema kapatma yöntemi pratik, basit, öngörülebilir ve uygun fiyatlı bir minimal invaziv tekniktir. Bu olgu sunumunda; restoratif diş hekimliğinde yaygın bir tedavi şekli olan diastema kapatma işleminin hastanın model üzerinde onayladığı ve bitim sonrasında da beğendiği restorasyonları daha sonrasında yaşadığı kararsızık sebebiyle 2 gün içinde söktürtmesi anlatılmaktadır. 24 yaşındaki bayan hasta üst ön dişleri arasındaki $\sim 4 \mathrm{~mm}$ genişliğindeki diastema şikâyeti ile kliniğimize başvurmuştur. Planlanan tedavi hakkında gerekli bilgilendirmeler yapıldıktan sonra hastamız restorasyonları onayladığına dair onam formunu imzalamış ve tedavilere başlanmış ve nanohibrit kompozit materyal ile restorasyonlar tamamlanmıştır. Sonuç olarak, kararsız hastalarda invaziv bir işleme başlamadan önce, hastanın yeni yapılan restorasyonlara alışma süresi de göz önünde bulundurularak, başlangıç tedavisi olarak kompozit lamina veneerleri tercih etmek çok daha yerinde bir tedavi yöntemi olacaktır.
\end{abstract}

\section{ANAHTAR KELIMELER}

Estetik, konservatif tedavi, diastema, algı

diastema, it generally occurs during childhood and may not be treated unless uneasiness or malfunctioning during chewing or speaking shows up. Those indications are usually experienced if the gap between the maxillary anterior is too wide $(>5 \mathrm{~mm})$. If it's not, patients' only complain about their teeth remains within the frame of esthetics. No matter what the cause of diastema, there are a number of different approaches to meet the requirement of patients. The common and the most

\footnotetext{
* Bu çalışma, 27-28 Ekim 2016 tarihlerinde, İstanbul'da düzenlenen, Restoratif Diş Hekimliği Derneği 20. Uluslararası Bilimsel Kongresi'nde sözlü olarak sunulmuștur.

${ }^{\alpha}$ Bezmialem Vakıf Üniversitesi Diş Hekimliği Fakültesi Restoratif Diş Tedavisi Anabilim Dalı, İstanbul

$\beta$ İstanbul Aydın Üniversitesi Diş Hekimliği Fakültesi Restoratif Diş Tedavisi Anabilim Dalı, İstanbul
} 
advised treatment is orthodontics as it gives a terminal and most desirable result for both patients and dentists however; it can sometimes be excluded due to the need of long time and the high expenses that the treatment requires. Nevertheless for the best result, orthodontic treatment model may not be sufficient alone. To give an example, orthodontics can't be the only treatment for 'peg shaped' lateral incisors or short clinical crowns; thus, the need for additional treatments occurs. Restorative or prosthodontics treatment is recommended if a patient is unwilling to wait for such timeneeded process and asks for a quick solution for diastema. ${ }^{2}$ With this object in mind, porcelain or composite veneers can be done. For the patient in this case report, composite veneers are chosen for the reason of being an alternative treatment option as it can be practiced cheaper, quicker and on chairside with excluding the laboratory procedures. The reason of using silicone index is the easiness in seeing the teeth from all angles by using a cast model. Changes in teeth can easily be recorded millimetrically by preparing a wax-up model and this also gives an opportunity to work without time limitation. In an all-inclusive manner, teeth can be viewed from every angle providing the clinicians to work without missing the milimetric details. Elaborated processed wax-up is easily transferred to the mouth with the help of silicone index. Thereby, the time by the chairside becomes very short. In this case, wide diastema (approximately 4 $\mathrm{mm}$ measured by a periodontal probe) between maxillary central incisor teeth were restored using a silicone key with the aim of providing a brief and a quick procedure for both the patient and the clinician.

\section{CASE PRESENTATION}

A 24 years old female patient with no systemic disease referred to Istanbul Aydin University Dentistry Faculty, Clinic of Restorative Dentistry Department complaining about maxillary anterior gap which affects her smile negatively for a long time in an esthetic manner. Clinical examination brought out a midline diastema between maxillary incisors wider than 3 millimeters (Figure 1).

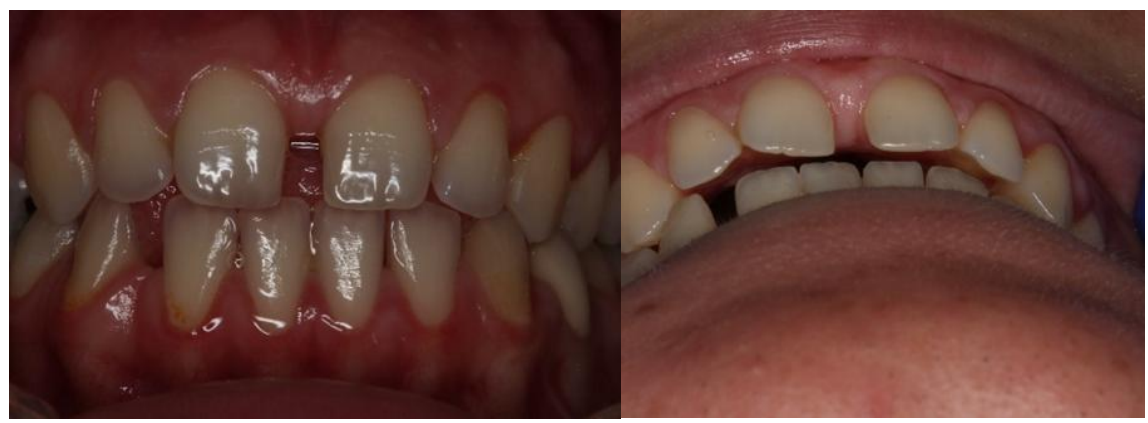

Figure 1.

The patient's initial appearance from different aspects

The patient was informed about the diagnosis. The most suitable treatment for the patient was decided together. Before the procedures, the patient was informed about the possible changes that may occur after the treatment such as that the patient may have her teeth bigger than before and may have difficulty in speaking, distention, and discomfort in her teeth. After that, to meet the patient's expectations from the treatment was explained on the diagnostic wax up model. The patient was concerned about the wax up model on the cast. She was very excited and curious about how would be the outcome. She wanted to find answers to many questions that were put on her mind. Before the restorative treatment in order to create a wax-up model, the patients' upper dental arch was molded by using condensational silicone impression material (Zetaflow Putty, Zhermack SpA,Via Bovazecchino, 100, 45021 Badia Polesine, Rovigo, Italy) (Lot number:176900). Later, the impression was casted with the hard dental plaster. The wax-up model was prepared on the plaster mold with white dental wax (Figure 2).

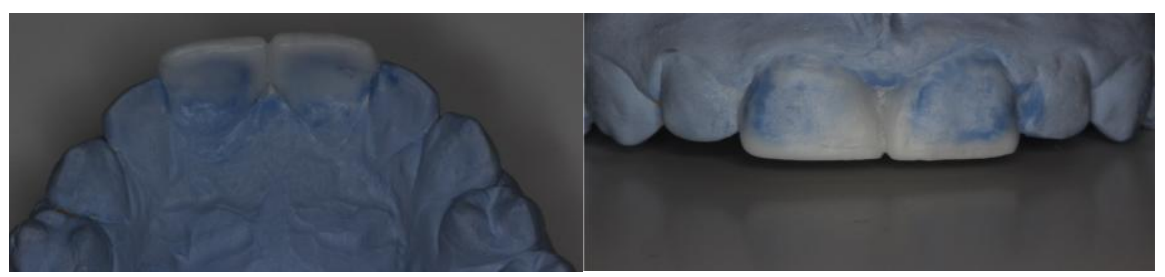

Figure 2.

Diagnostic wax-up models on the cast from different aspects

After that, the silicone index was prepared with additional silicone (Elite P\&P Hydrophilic, Zhermack SpA,Via Bovazecchino, 100, 45021 Badia Polesine, Rovigo, Italy) (Lot number:186290) (Figure 3). Three different silicone index was used during treatment for this case. First one was used to see palatal surface, the second one to see the labial surface and the third one to see the tooth thickness labio-lingually (Figure 4). 


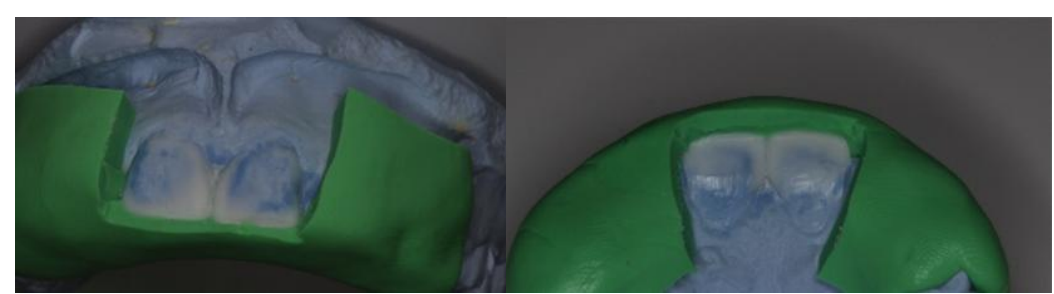

Figure 3.

The silicone indexes on the wax up model

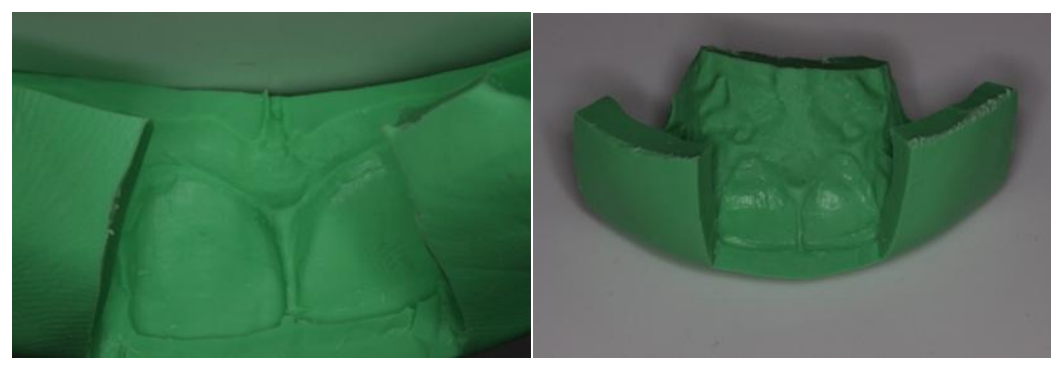

Figure 4.

The appearance of the silicone indexes from both labial and palatal sides

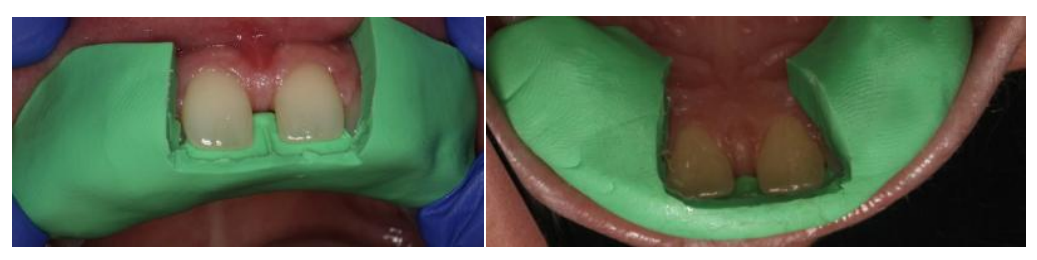

Figure 5 .

The silicone index in the patient's mouth before the procedure from different aspects

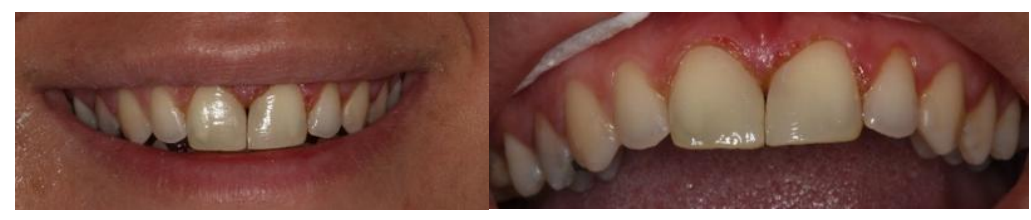

Figure 6.

The final appearance just after the treatment



Figure 7.

The appearance of teeth and diastema after the removal procedure (Duration of the restorations less than 2 days)
Every silicone index was tested before the procedure (Figure 5). After that cotton pellets were placed under the lips to create secure working area. No preparation was planned on the teeth. The enamel was etched with $37 \%$, orthophosphosphoric acid (Scotchbond $^{\mathrm{TM}}$ Universal Etchant, 3M ESPE, 3M Deutschland GmbH, 41453 Neuss Germany) (Lot Number: 625669) for 30 seconds and then rinsed with water. The bonding agent (Adper ${ }^{\mathrm{TM}}$ Single Bond 2, 3M ESPE, USA) (Lot Number: N561932) was applied with a microbrush. The bonding agent was cured for 10 seconds with Light Emitting Diodes (LED) light curing unit (Elipar ${ }^{\mathrm{TM}}$, LED Curing Light3M ESPE, USA) (light output; $\left.1200 \mathrm{~mW} / \mathrm{cm}^{2}\right)$. The silicone index was positioned and palatal shell was created with dentin composite (Enamel plus HRI UD2, Manufacturer: GDF GmbH 61191-Rosbach, Germany Distributor: Micerium S. p. A. 16036 Avegno (GE), Italy) (Lot Number: 2013002675) firstly. Dentin composite was used at the first increment layer in order to compensate the translucency. After that, enamel composite (Enamel plus HRI UE1, Manufacturer: GDF GmbH 61191-Rosbach, Germany Distributor: Micerium S. p. A. 16036 Avegno (GE), Italy) (Lot Number: 2014002751) was layered via increment layering technique. Finishing and polishing procedure was performed with Soflex Discs (Sof-Lex ${ }^{\mathrm{TM}}$ XT Discs, 3M ESPE, USA) (from coarse to fine) vestibule surface and on both labial and palatal side of the interproximal area of the restoration for a fine and smooth interproximal area and also yellow banded flame shaped bur was used on the tooth and gingiva conjunction. In order to obtain tooth like glossy surface, composite laminate veneers were polished with Enamel Plus Polishing Set (Enamel Plus Shiny Kit, Micerium S.p.A. Via G. Marconi, 83 - Avegno (GE) Italy) (Lot Number:1602048) (Figure 6).

At last, it was reminded that the patient might find her teeth much bigger than before and there might be an adjustment process so a control appointment was given to the patient for the following day to control her recovery. Even though the treatment steps were explained perfectly 
and the consent form was signed by the patient, she called back the clinic the day after with the complain of the veneers. The patient asked the veneers to be removed instantly. This was quite unusual for a clinician to be asked as the patient's request for esthetics was accomplished successfully yet the appearance did not satisfy her. In order to shed light on the issue, the patient was asked to come the control appointment in the following morning. She kept her complains about veneers in almost a childish manner. Once again, it was advised to the patient that she would be adapted with the veneers in couple of days. Still the patient kept her complaints and she also stated that she had a difficulty in speaking. In response to this, it was told her that it was quite natural to experience such disturbance to a degree and if she would give enough time for the recovery, the uneasy feeling in the teeth would pass over time. It was also explained to the patient that she would be complied with the newly done teeth. Unfortunately, as the patient informed us later, those complains which were stated kept continuing. As a result, the patient made her statement about the treatment once again and she asked the veneers to be removed instantly. After that the consent form was taken to indicate that the patient was willing to get through the procedure and aware of everything. Then, the veneers were started to be removed with the coarsest Sof-Lex Discs in order not to destroy the healthy tooth structure. The removing procedure was done (Figure 7). After that, the patient confessed that she was pleased with the previous look of her teeth before the treatment alongside with her boyfriend and her relatives. She stated that neither she nor her relatives like the diastema closure treatment at all and they would prefer the original look of her teeth were more beautiful and socially acceptable for their community.

\section{DISCUSSION}

Diastema closure cases can be both restored with porcelain and composite laminate veneers. Porcelain laminate veneers can be made by traditional laboratory techniques or computer-aided design and computeraided manufacturing (CAD/CAM) technology.

Porcelain laminate veneers produced with traditional laboratory techniques requires an impression of the prepared teeth, and the opposing arch, preparation of casts, and extensive laboratory time. ${ }^{2}$ The advances in dental materials and computer technology have made CAD/CAM-fabricated restorations available for dentistry. Furthermore, this approach supports a chairside workflow for the restoration, and fabrication in a single visit using prefabricated ceramic blocks. ${ }^{3} \mathrm{~A}$ single visit protocol for the fabrication of a porcelain veneer allows better control of the shade and contour and is less time-consuming for the patient and the and the clinician. ${ }^{4}$ But certainly these terms can also be obtained with composite veneer restorations.

Ceramics are often mentioned as the material of choice, with positive properties due to their higher fracture resistance and color stability. ${ }^{5}$ However, composites have also showed to offer excellent esthetic and mechanical results. ${ }^{6}$ Moreover, in comparison to all-ceramic restorations, composite materials have no potential for brittle fracture and abrasive wear of the opposing teeth., ${ }^{7,8}$ The problematic repair of a fractured porcelain laminate veneer is another issue. While small fractures may be corrected by a contouring of the restoration, large fractures necessitate the technically difficult reparation with a direct composite $^{9}$ or the replacement of the restoration. ${ }^{10}$ The composite veneers can be more easily repaired. Also, in the clinical cases of diastema closure, direct composite restorations make the procedure practical and time saving to make the esthetic correction of anterior teeth. $^{2}$ Due to these advantages, composite material was chosen for the closure of the diastema in this case report.

Right after the restorations, although the patient was very pleased with the treatment, dissatisfaction occurred after the patient started to use the veneers. This can be due to the quite wide diastema closure which created difficulty in eating foods, articulating certain sounds like ' $s$ '. Second fact can be the new veneers that the patient was not accustomed and found strange. The third one is the comments that she heard from the environment, especially from the family members. Despite all the efforts to assure her, the result would be pleasing if she had given enough time and chance for the restorations.

Expectations from a dental procedure are very important for both clinician and the patient. Although the outcome was quite satisfying for the clinician, it was not for the patient. At this point, the aesthetic expectation of the patient should be perceived by the clinician and the aesthetic perception of the patient should be taken into consider.

\section{CONCLUSIONS}

Before any invasive restorations like porcelain or CAD/CAM laminate veneers, it may be a sounder decision to use primarily composite veneers for the initial treatment which is a more minimally invasive procedure for the indecisive patients like in this case. Before performing such treatments which can directly affect the image of a person, it can be asked that somebody from family or a trustworthy friend of the patient to accompany with the 
performance. Besides, taking consent form from the patients who are not sure about what they really imagine can protect the clinician from such troubled occasions like this. This rare case report is a candidate for the possible malpractice prosecutions which is one of the most important topics for today's dentistry.

It is necessary to give them time to be more cautious in patients who are indecisive and unstable in the patient selection and to be able to fully clarify the subject of the procedure to be done. In addition, this type of patients can be effective in showing the images of the cases that have made before. It must be clear that the clinician never be insist of the procedure which was planned and the final decision is belonged to be the patients themselves. Finally, this diastema closure case prepared by silicone index on a wax up model with composite material was a successful treatment, in terms of restorative dentistry.

\section{REFERENCES}

1. Muthu M, Rathna P, Koora K. Spontaneous closure of midline diastema following frenectomy. J Indian Soc Pedod Prev Dent 2007; 25: 23-6.

2. Araujo EMD, Fortkamp S, Baratieri LN. Closure of diastema and gingival reconturing using direct adhesive restorations: a case report. J Esthet Restor Dent 2009; 21: 229-40.

3. Santos Jr. GC, Boksman LL, Santos MJ. CAD/CAM technology and esthetic dentistry: a case report. Compend Contin Educ Dent 2013; 34: 764-70.

4. Schlichting LH, Resende TH, Reis KR, Magne P. Simplified treatment of severe dental erosion with ultrathin CAD/CAM composite occlusal veneers and anterior bilaminar veneers. $\mathrm{J}$ Prosthet Dent 2016; 116: 474-82.

5. D'Arcangelo $C$, De Angelis F, Vadini M, D'Amario M. Clinical evaluation on porcelain laminate veneers bonded with lightcured composite: results up to 7 years. Clin Oral Investig 2012; 16: 1071-9.

6. Rappelli G, Coccia E, Putignano A. Restoration of anterior teeth with indirect composite partial coverage crowns: a clinical report. J Prosthet Dent 2004; 92: 519-22.

7. Nakamura $T$, Imanishi $A$, Kashima $H$, Ohyama $T$, Ishigaki $S$. Stress analysis of metal-free polymer crowns using the threedimensional finite element method. Int J Prosthodont 2001; 14: $401-5$.

8. D'Arcangelo C, Vanini L, Rondoni GD, Pirani M, Vadini M, Gattone $\mathrm{M}$, et al. Wear properties of a novel resin composite compared to human enamel and other restorative materials. Oper Dent 2014; 39: 612-18.

9. Blatz MB, Sadan A, Kern M. Resin-ceramic bonding: a review of the literature. J Prosthet Dent 2003; 89: 268-74.

10. Horvath S, Schulz CP. Minimally invasive restoration of a maxillary central incisor with a partial veneer. Eur J Esthet Dent 2012; 7: 6-16.

11.Garber D. Porcelain laminate veneers: ten years later-part I: tooth preparation. J Esthet Dent 1993; 5: 56-62.;

12.Gresnigt MM, Kalk W, Ozcan M. Randomized clinical trial of indirect resin composite and ceramic veneers: up to 3-year follow-up. J Adhes Dent 2013; 15: 181-90.

13. Korkut B, Yanikoglu F, Tagtekin D. Direct midline diastema closure with composite layering technique: a one-year followup. Case Rep Dent 2016; 2016: 1-5.

Corresponding Author:

Arş.Gör. Sevda ÖZTÜRK

İstanbul Aydın Üniversitesi

Diş Hekimliği Fakültesi

Restoratif Diş Tedavisi AD

Beşyol Mah., Küçükçekmece, İstanbul

Phone: +90 2124113000

Fax: +902124116240

E-mail: sevdaozturk@aydin.edu.tr 